\title{
Chymase in Exocytosed Rat Mast Cell Granules Effectively Proteolyzes Apolipoprotein Al-containing Lipoproteins, So Reducing the Cholesterol Efflux-inducing Ability of Serum and Aortic Intimal Fluid
}

\author{
Leena Lindstedt, ${ }^{*}$ Miriam Lee, ${ }^{*}$ Graciela R. Castro, ${ }^{\ddagger}$ Jean-Charles Fruchart, ${ }^{\ddagger}$ and Petri T. Kovanen ${ }^{*}$ \\ *Wihuri Research Institute, Kalliolinnantie 4, 00140 Helsinki, Finland; and ${ }^{\ddagger}$ SERLIA \& INSERM U.325, Pasteur Institute, 59019 Lille, \\ France
}

\begin{abstract}
Degranulated mast cells are present in human fatty streaks. Chymase in granules released from degranulated rat serosal mast cells, i.e., in granule remnants, proteolyzes human high density lipoprotein ${ }_{3}\left(\mathrm{HDL}_{3}\right)$, and so reduces its ability to induce cholesterol efflux from macrophage foam cells in vitro. In this study we found that remnant chymase, by proteolyzing human serum and human aortic intimal fluid, prevents these two physiologic fluids from effectively inducing cholesterol efflux from cultured macrophage foam cells. Inhibition was strongest when remnants were added to apolipoprotein AI (apoAI)-containing lipoproteins; the remnants had no effect on the weaker efflux produced by apoAI-deficient serum. Western blot analysis showed that granule remnants degrade apoAI in serum and in intimal fluid. When released from remnants, chymase lost its ability to proteolyze $\mathrm{HDL}_{3}$ in the presence of serum. Thus, remnant chymase (but not isolated chymase) was able to resist the natural protease inhibitors present in serum and in intimal fluid. The results imply participation of exocytosed mast cell granules in foam cell formation in atherogenesis. (J. Clin. Invest. 1996. 97:2174-2182.) Key words: apolipoprotein AI • cellular cholesterol efflux • foam cells • mast cells • neutral proteases
\end{abstract}

\section{Introduction}

Elevated levels of plasma high density lipoprotein (HDL) are associated with a low risk of coronary heart disease in humans (1). Moreover, injection of rabbit HDL into cholesterol-fed rabbits has been shown to lead to regression of atherosclerotic lesions in these animals (2). The antiatherogenic action of HDL particles is thought to arise largely from their ability to accept excess cholesterol from cells, notably from those present in the arterial intima (3) (the site of atherogenesis) and to transport it back into the circulation, and ultimately to the liver (4). The initial step of this reverse cholesterol transport system is efflux of cholesterol from cells to HDL particles (5). Efficient efflux of cholesterol to HDL is crucial for prevention

Address correspondence to Petri T. Kovanen, Wihuri Research Institute, Kalliolinnantie 4, 00140 Helsinki, Finland. FAX: 358-0-637476. Miriam Lee's present address is Faculty of Biology, University of Havana, Vedado, Havana, Cuba.

Received for publication 6 February 1995 and accepted in revised form 27 February 1996.

J. Clin. Invest.

(C) The American Society for Clinical Investigation, Inc.

0021-9738/96/05/2174/09 \$2.00

Volume 97, Number 10, May 1996, 2174-2182 of cholesterol accumulation in macrophages, in which ingestion of lipoproteins is not inhibited by the inflowing cholesterol (6). In these cells, scavenger receptor-mediated or phagocytic uptake of lipoproteins may result in rapid and massive cellular accumulation of cholesterol, with formation of the foam cells typical of atherosclerotic lesions (7-9).

Insufficient efflux of cholesterol from foam cells to HDL results when concentrations of these acceptor particles are too low, or from changes in their function. We recently observed that the ability of human $\mathrm{HDL}_{3}$ to remove cholesterol from macrophage foam cells in vitro is efficiently blocked when the $\mathrm{HDL}_{3}$ undergoes modification by the mast cell neutral protease chymase (10). Chymase is present in the cytoplasmic secretory granules of mast cells (11). The cytoplasm of rat serosal mast cells, our model cell, is filled with secretory granules which are expelled into the extracellular fluid when the mast cells are stimulated (12). In the extracellular fluid, the soluble components of the granules, such as histamine, chondroitin sulfate proteoglycans, and a fraction of the heparin proteoglycans, are released and diffuse away. In contrast, the major granule components, the two neutral proteases chymase and carboxypeptidase A, and the majority of the heparin proteoglycans, remain tightly bound to each other, forming extracellular granule remnants (13). If mast cells are cocultured with macrophage foam cells in a medium enriched with $\mathrm{HDL}_{3}$, and then stimulated to degranulate, the ability of the $\mathrm{HDL}_{3}$ particles to induce cholesterol efflux is largely lost when the chymase of the granule remnants proteolyzes the $\mathrm{HDL}_{3}$ particles.

Mast cell granule remnants also bind low density lipoprotein (LDL) particles, and carry them into macrophages as the macrophages phagocytose the LDL-loaded remnants (14). The efficiency of this carrier function is greatly enhanced when the neutral proteases of the granule remnants proteolyze the apolipoprotein B-100 component of the remnant-bound LDL particles, whereupon the proteolyzed particles become unstable and fuse into larger particles on the surface of the remnants, so allowing more LDL particles to be bound to remnants. Thus chymase, by degrading the apolipoproteins of both HDL and LDL particles render the stimulated mast cells powerful inductors of cholesterol accumulation in macrophages in vitro.

Mast cells are also present in human aortic and coronary fatty streaks, and a significant fraction of the mast cells in these lesions is degranulated, as shown by the presence of chymasecontaining granule remnants in the the extracellular space near the activated mast cells and foam cells (15-17). In contrast to the incubation medium in the in vitro system described above, which was devoid of plasma proteins, the extracellular fluids, such as the arterial intimal fluid, contain the physiological inhibitors of chymase $\alpha_{1}$-antitrypsin, $\alpha_{1}$-antichymotrypsin, and $\alpha_{2}$-macroglobulin $(18,19)$. To elucidate the potential of the 
exocytosed mast cell granules in the arterial intima to modify HDL proteolytically, we incubated HDL with granule remnants in extracellular fluid obtained from human aortic intimas. We show that granule chymase in its physiological form, i.e., when bound to the heparin proteoglycans in granule remnants, although not when released from them, is able to proteolyze the HDL in intimal fluid, and so renders the intimal fluid a less efficient acceptor of cellular cholesterol.

\section{Methods}

Animals. Male Wistar rats (300-500 grams) were from the Laboratory Animal Center of the University of Helsinki, and female NMRI mice (20-30 grams) were purchased from a licensed center (Poikkijoki, Kuvaskangas, Finland).

Preparation of mast cell suspensions and isolation of exocytosed mast cell granules. Serosal mast cells were isolated from peritoneal and pleural cavities of rats. The isolated mast cells were stimulated to degranulate with compound 48/80 (Sigma Chemical Co., St. Louis, $\mathrm{MO})$ and the exocytosed granules, i.e., granule remnants, were isolated from the released material, as described (9). The quantity of granule remnants is expressed in terms of their protein content or proteolytic activity with $N$-benzoyl-L-tyrosine ethyl ester (BTEE) ${ }^{1}$ as substrate.

Isolation of chymase from granule remnants. The method of chymase isolation is based on the known high binding affinity of chymase for heparin. Granule remnants were first resuspended in $10 \mathrm{mM}$

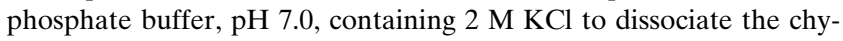
mase from the heparin proteoglycans (20), and the mixture was applied in the same buffer to a Sephacryl S-200 column $(1 \times 50 \mathrm{~cm}$, Pharmacia LKB Biotechnology, Uppsala, Sweden). The column was eluted with the same buffer at a flow rate of $5 \mathrm{ml} / \mathrm{h}$ at $4^{\circ} \mathrm{C}$, and the eluted fractions were tested spectrophotometrically for their chymase activity, using BTEE as substrate (21) with modifications (22). Unit definition: 1 BTEE unit corresponds to a 0.001 increase in absorbance at $256 \mathrm{~nm} / \mathrm{min}$, when $0.5 \mathrm{mM}$ BTEE is used as substrate, in 3 $\mathrm{ml}$ of $50 \mathrm{mM}$ Tris- $\mathrm{HCl}, \mathrm{pH} 7.4$, at $25^{\circ} \mathrm{C}$. The fractions containing chymase were diluted with $10 \mathrm{mM}$ phosphate buffer to give a final concentration of $0.5 \mathrm{M} \mathrm{KCl}$, and applied in this buffer to a HiTrap Heparin column ( $1 \mathrm{ml}$, Pharmacia LKB Biotechnology). The column was then washed with the above buffer, and chymase was eluted by increasing the concentration of $\mathrm{KCl}$ to $1 \mathrm{M}$, and stored in this buffer at $-20^{\circ} \mathrm{C}$. Before experiments, the chymase-containing fractions were diluted with $5 \mathrm{mM}$ Tris- $\mathrm{HCl}, 1 \mathrm{mM}$ EDTA, $\mathrm{pH} 7.4$, to give a final concentration of $150 \mathrm{mM} \mathrm{KCl}$.

PMSF inactivation of granule remnants. Granule remnants were incubated in $5 \mathrm{mg} / \mathrm{ml} \mathrm{BSA}, 1 \mathrm{mM}$ EDTA, $5 \mathrm{mM}$ Tris- $\mathrm{HCl}$, $\mathrm{pH} 7.4$, with $250 \mu \mathrm{g} / \mathrm{ml} \mathrm{PMSF}$, at $37^{\circ} \mathrm{C}$ for $15 \mathrm{~min}$. After incubation, the granule remnants were washed with $5 \mathrm{mg} / \mathrm{ml} \mathrm{BSA,} 1 \mathrm{mM}$ EDTA, $5 \mathrm{mM}$ Tris- $\mathrm{HCl}, \mathrm{pH} 7.4$, and their inactivation $(>99 \%$ ) was verified by measuring chymase activity spectrophotometrically with BTEE as substrate.

Preparation of mouse and human macrophage monolayers. Peritoneal cells were harvested from unstimulated mice in phosphate-buffered saline (PBS) (GIBCO, Paisley, Scotland) containing $1 \mathrm{mg} / \mathrm{ml}$ BSA (23). Cells were pooled, centrifuged, and resuspended in DMEM (GIBCO) with $100 \mathrm{U} / \mathrm{ml}$ penicillin and $100 \mu \mathrm{g} / \mathrm{ml}$ streptomycin (medium A) supplemented with $20 \%$ fetal calf serum, and plated at $1 \times 10^{6}$ cells per well into 24-well plates (Becton Dickinson Labware, Lincoln Park, NY). After incubation at $37^{\circ} \mathrm{C}$ for $2 \mathrm{~h}$ in humidified $\mathrm{CO}_{2}(5 \%)$, the nonadherent cells were removed by rinsing the monolayers with PBS, and cholesterol loading of the macrophages

1. Abbreviations used in this paper: BTEE, $N$-benzoyl-L-tyrosine ethyl ester; LpAI, apolipoprotein AI containing lipoproteins; VHDL, very high density lipoprotein. was started. Human monocyte-derived macrophages were separated from buffy coat cells by diluting buffy coats (kind gifts from the Finnish Red Cross Blood Transfusion Service, Helsinki) with three volumes of Dulbecco's phosphate-buffered saline lacking both $\mathrm{Ca}^{2+}$ and $\mathrm{Mg}^{2+}$. Mononuclear cells were then isolated by centrifugation of the diluted buffy coat on Ficoll-Paque (Pharmacia LKB Biotechnology) at $600 \mathrm{~g}$ at $20^{\circ} \mathrm{C}$ for $15 \mathrm{~min}$. The mixed mononuclear cell band was removed by aspiration and washed three times with $\mathrm{Ca}^{2+}$ - and $\mathrm{Mg}^{2+}$ free PBS. The cells (25-30\% of which were monocytes) were resuspended in medium A, seeded in 24 -well plates $\left(5 \times 10^{6}\right.$ cells per well $)$, and allowed to adhere for an hour. Nonadherent cells were washed off and medium A supplemented with 20\% serum (pooled from healthy donors) was added. The medium was replaced after $24 \mathrm{~h}$ and every $48 \mathrm{~h}$ thereafter. On day 7 of culture, cholesterol loading of monocyte-derived macrophages was started.

Loading of macrophages with cholesteryl esters. To load the mouse macrophages with cholesteryl esters, the cells were incubated for $18 \mathrm{~h}$ in the presence of $20 \mu \mathrm{g} / \mathrm{ml}$ of ${ }^{3} \mathrm{H}$-labeled acetyl-LDL in medium A containing $20 \%$ fetal calf serum. Similarly, human monocyte-derived macrophages were loaded for $2 \mathrm{~d}$ with cholesterol by incubating them in medium A containing $5 \mathrm{mg} / \mathrm{ml}$ of lipoprotein-deficient serum in the presence of $25 \mu \mathrm{g} / \mathrm{ml}$ of ${ }^{3} \mathrm{H}$-labeled acetyl-LDL. To study the net efflux (mass movement of cholesterol) from cholesterol-loaded macrophages (of either mouse or human origin), macrophage monolayers were loaded with LDL-derived cholesterol by incubating them in the same conditions as above, except that unlabeled acetyl-LDL was used.

Serum. Blood was collected from normal healthy donors after overnight fasting or from one autopsy case for the measurement of $\alpha_{1}$-antitrypsin concentration in serum. Serum from healthy donors was used immediately for experiments in which cholesterol efflux was measured.

Isolation of lipoprotein fractions, apoAI-containing particles from serum (LpAI-particles), lipoprotein-deficient serum, and apoAI-deficient serum. Human LDL $(d=1.019-1.063 \mathrm{~g} / \mathrm{ml}), \mathrm{HDL}_{2}(d=1.063-$ $1.125 \mathrm{~g} / \mathrm{ml}), \mathrm{HDL}_{3}(d=1.125-1.210 \mathrm{~g} / \mathrm{ml})$, very high density lipoprotein (VHDL) $(d=1.210-1.250 \mathrm{~g} / \mathrm{ml})$, and lipoprotein-deficient serum (LPDS) $(d>1.250 \mathrm{~g} / \mathrm{ml})$ were isolated from fresh plasma of normal healthy donors by sequential ultracentrifugation, using $\operatorname{KBr}(24,25)$. $\mathrm{HDL}_{3}$ particles were applied to a heparin column, and then separated according to their apolipoprotein content into particles containing apoAI and apoAII ([HDL ${ }_{3}(\mathrm{AI}$ w AII $\left.)\right]$ and particles containing apoAI but not apoAII [ $\mathrm{HDL}_{3}(\mathrm{AI}$ w/o AII $\left.)\right]$ on a combination of anti-apoAI-and anti-apoAII-immunosorbent columns, and similarly apoAI-containing particles (LpAI) from serum were separated by immunoaffinity chromatography according to Barbaras et al. (26). The purity of the AI and AII particles and the absence of apoAI from the LpAI-deficient serum were verified by Western blot analysis (27) (data not shown).

Lipoprotein modifications. LDL was acetylated (acetyl-LDL) by repeated additions of acetic anhydride $(28)$. $\left[{ }^{3} \mathrm{H}\right]$ Cholesteryl linoleate $\left(1,2(\mathrm{n})\left[{ }^{3} \mathrm{H}\right]\right.$ cholesteryl linoleate, $30-60 \mathrm{Ci} / \mathrm{mmol}$ ) (Amersham International, Arlington Heights, IL) was incorporated into acetyl-LDL by incubating $1 \mathrm{mg}$ acetyl-LDL and $40 \mu \mathrm{Ci}\left[{ }^{3} \mathrm{H}\right]$ cholesteryl linoleate in $10 \%$ dimethylsulfoxide (29), which yielded preparations with specific activities ranging from 30 to $100 \mathrm{dpm}$ of $\left[{ }^{3} \mathrm{H}\right]$ cholesteryl linoleate/ng protein. $\mathrm{HDL}_{3}$ was iodinated with ${ }^{125} \mathrm{I}\left(\mathrm{Na}^{125} \mathrm{I}, 15-16 \mathrm{mCi}\right.$ ${ }^{125} \mathrm{I}$ per microgram of iodine) (Amersham International) by the iodine monocholoride method to yield specific activities of 390-400 $\mathrm{dpm} / \mathrm{ng}(30,31)$. Before each experiment, ${ }^{125} \mathrm{I}-\mathrm{HDL}_{3}$ was diluted with unlabeled $\mathrm{HDL}_{3}$ to a specific activity of $0.5 \mathrm{dpm} / \mathrm{ng}$. The concentrations of lipoproteins are given in terms of their protein content.

Measurement of $\left[{ }^{3} \mathrm{H}\right]$ cholesterol efflux from macrophage foam cells. $\left[{ }^{3} \mathrm{H}\right]$ cholesterol-loaded macrophages (of either mouse or human origin) were washed with PBS, and the cells were immersed in fresh medium A. Cholesterol acceptors were added to give the final concentrations indicated in the figure legends, and the mixtures were incubated in the presence or absence of mast cell granule remnants at 


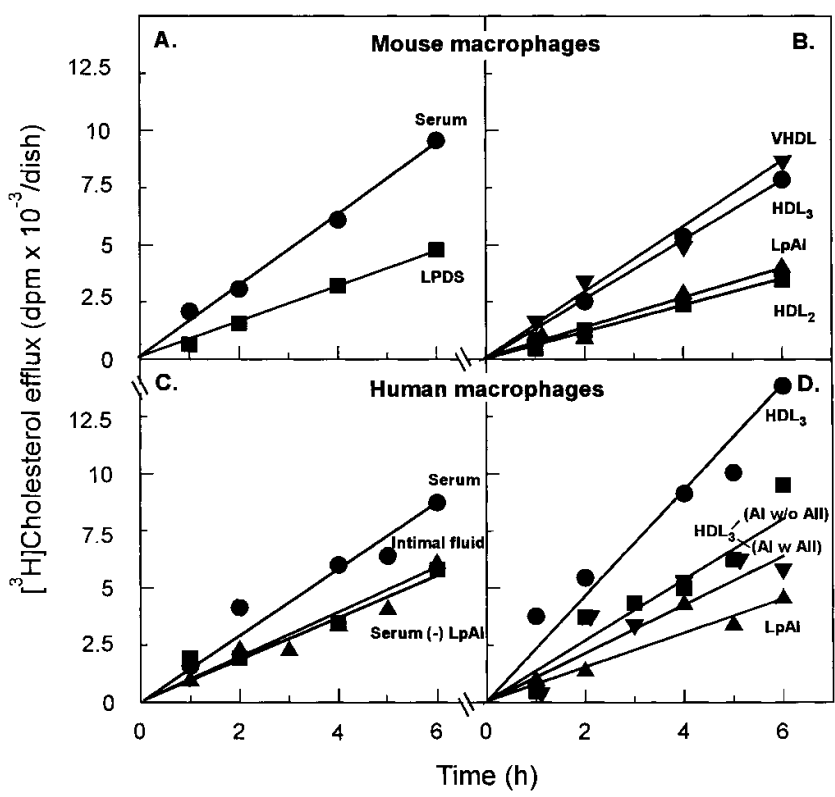

Figure 1. Cholesterol efflux from ( $A$ and $B$ ) mouse macrophage foam cells and from $(C$ and $D)$ human monocyte-derived macrophage foam cells induced by various cholesterol acceptors. ( $A$ and $B$ ) Mouse macrophage monolayers were incubated for $18 \mathrm{~h}$ in $300 \mu \mathrm{l}$ of medium A supplemented with $20 \%$ fetal calf serum and $20 \mu \mathrm{g} / \mathrm{ml}$ of ${ }^{3} \mathrm{H}$-labeled acetyl-LDL. The $\left[{ }^{3} \mathrm{H}\right]$ cholesterol-loaded macrophage foam cells were then washed, and $300 \mu \mathrm{l}$ of medium A, containing the indicated cholesterol acceptors, was added. The final concentrations of the acceptors were: serum and LPDS (7.5 mg/ml); VHDL, $\mathrm{HDL}_{3}, \mathrm{HDL}_{2}$, and LpAI $(100 \mu \mathrm{g} / \mathrm{ml}$ each). ( $C$ and $D)$ Human monocyte-derived macrophages were incubated for $48 \mathrm{~h}$ in $300 \mu \mathrm{l}$ of medium A supplemented with $5 \mathrm{mg} / \mathrm{ml}$ lipoprotein-deficient serum and $25 \mu \mathrm{g} / \mathrm{ml}$ of ${ }^{3} \mathrm{H}$ labeled acetyl-LDL. The $\left[{ }^{3} \mathrm{H}\right]$ cholesterol-loaded macrophage foam cells were then washed, and $300 \mu \mathrm{l}$ of medium A, containing the indicated cholesterol acceptors, was added. The final concentrations of the acceptors were: serum and LpAI-deficient serum [(Se$\operatorname{rum}(-) \mathrm{LpAI})](7.5 \mathrm{mg} / \mathrm{ml})$; intimal fluid $(2.5 \mathrm{vol} \%) ; \mathrm{HDL}_{3}$, $\mathrm{HDL}_{3}$ (AI w/o AII), $\mathrm{HDL}_{3}$ (AIw AII), and LpAI (100 $\mu \mathrm{g} / \mathrm{ml}$ each). The macrophages (in $A, B, C$ and $D$ ) were incubated with the various acceptors for the indicated times at $37^{\circ} \mathrm{C}$, the media were collected, their ${ }^{3} \mathrm{H}$ radioactivities were determined, and plotted as a function of time. Human monocytes were obtained from several donors and, therefore, the absolute efflux rates are not comparable.

$37^{\circ} \mathrm{C}$ for $6 \mathrm{~h}$ in a humidified $5 \% \mathrm{CO}_{2}$ incubator. After incubation, the media were collected and centrifuged at $200 \mathrm{~g}$ for $5 \mathrm{~min}$ to remove any detached cells or cellular debris, and the ${ }^{3} \mathrm{H}$ radioactivity in the supernatant was measured by liquid scintillation counting. Thin-layer chromatography showed that most $(95 \%)$ of the radioactivity was present in the free cholesterol fraction. From each value, the corresponding blank value (medium without acceptor) was subtracted. Each point in the figures represents the mean of duplicate incubations of a single experiment. Each experiment was performed at least twice, and in each case the results obtained were similar. The linearity of the $\left[{ }^{3} \mathrm{H}\right]$ cholesterol efflux was tested for each experimental system used in this study. For this purpose, both mouse and human macrophages were incubated for up to $6 \mathrm{~h}$ with the highest concentrations of the acceptors used in the experiments. In each case, the efflux was found to be linear (Fig. 1).

Measurement of cholesterol net efflux from macrophage foam cells. Cholesterol-loaded macrophages (of either mouse or human origin) were washed, and the cell lipids were extracted with hexane: isopropanol $(3: 2 \mathrm{vol} / \mathrm{vol})$, and applied to Bond Elute ${ }^{\circledR}$ columns $\left(\mathrm{NH}_{2}-\right.$ bonded silica; Varian, Harbor City, CA) to separate cholesteryl esters from fatty acids and phospholipids. The cholesteryl esters (palmitate, oleate, and linoleate) were then determined by HPLC as described before (32). For protein measurements, the macrophages were then treated with $0.2 \mathrm{~N} \mathrm{NaOH}$. Incubations were carried out in triplicate.

Western blots of apoAI and apoAII in granule remnant-treated serum. Intimal fluid $(2 \%)$, serum $(1 \%)$, LpAI $(1 \mathrm{mg} / \mathrm{ml})$, or $\mathrm{HDL}_{3}(1$ $\mathrm{mg} / \mathrm{ml}$ ) were incubated at $37^{\circ} \mathrm{C}$ for $18 \mathrm{~h}$ in $50 \mu \mathrm{l}$ of $150 \mathrm{mM} \mathrm{NaCl}, 1$ $\mathrm{mM}$ EDTA, $5 \mathrm{mM}$ Tris- $\mathrm{HCl}, \mathrm{pH} 7.4$, in the presence or absence of 5 $\mu \mathrm{g}$ of granule remnants. After incubation, aliquots of treated and untreated samples at appropriate dilutions and molecular weight standards (Kaleidoscope Prestained Standards; Bio-Rad Laboratories, Hercules, CA) were applied to a $15 \%$ SDS-PAGE in nonreducing conditions (33), transferred to a nitrocellulose membrane, and apoAI and apoAII were immunolocalized with the appropriate monoclonal anti-human apolipoproteins.

Proteolysis of $\mathrm{HDL}_{3}$ by granule remnants and by isolated chymase in the presence of serum or intimal fluid. ${ }^{125} \mathrm{I}_{-} \mathrm{HDL}_{3}(0.6 \mathrm{mg} / \mathrm{ml})$ was incubated at $37^{\circ} \mathrm{C}$ for $2 \mathrm{~h}$ in $20-100 \mu \mathrm{l}$ of $150 \mathrm{mM} \mathrm{NaCl}, 1 \mathrm{mM}$ EDTA, $5 \mathrm{mM}$ Tris-HCl, $\mathrm{pH} 7.4$, with granule remnants, isolated chymase, or $\alpha$-chymotrypsin (Sigma Chemical Co.) (each containing 170 BTEE $\mathrm{U} / \mathrm{ml}$ ), in the presence of the indicated concentrations of serum or intimal fluid. After incubation, the incubation mixtures were treated with $10 \%$ TCA to determine the amount of TCA-soluble radioactivity. The values of ${ }^{125} \mathrm{I}_{-} \mathrm{HDL}_{3}$ degradation in the presence of serum or intimal fluid (inhibition of proteolysis) are expressed as percentages of the degradation in control incubations carried out in buffer (which was set to $100 \%$ ). Degradation in the control incubations varied between 8 and $23 \%$, i.e., $8-23 \%$ of the radioactivity present in ${ }^{125} \mathrm{I}$ $\mathrm{HDL}_{3}$ was converted into TCA-soluble material upon incubation with granule remnants (see Fig. 7). The degree of proteolytic inhibition of a given serum or intimal fluid concentration did not depend on the absolute degree of ${ }^{125} \mathrm{I}_{-} \mathrm{HDL}_{3}$ degradation. For experiments with human monocyte-derived macrophages, intimal fluid $(2.5 \%)$ or $\mathrm{HDL}_{3}(1 \mathrm{mg} / \mathrm{ml})$ was pretreated by incubation in the absence or presence of $0.05 \mathrm{mg} / \mathrm{ml}$ of granule remnants in medium A at $37^{\circ} \mathrm{C}$ for $18 \mathrm{~h}$. After incubation, the granules were removed by centrifugation and the supernatant was applied to macrophage monolayers.

Preparation of aortic intimal fluid. The autopsy samples comprised six subjects (5 male and 1 female) aged 36 to 51 years. The causes of death were gastrointestinal bleeding (2), violent deaths (3), and alcohol intoxication (1). The mean interval between death and the start of collection of intimal fluid was $12 \mathrm{~h}$ (range 7-16 h). Extracellular fluid was obtained from the intimal layer of grossly normal-looking areas of the thoracic and abdominal aorta by the filter paper method of Smith and Staples (34). Light microscopic examination of the fixed and stained samples showed that the filter paper was located within the intimal layer of the aortas. The fluid was collected from the soaked pieces of filter paper by placing them in $0.5 \mathrm{ml}$ microtubes (with a slit at their tips) which were placed in $1.5 \mathrm{ml}$ microtubes, and centrifuging at $20,000 \mathrm{~g}$ for $10 \mathrm{~min}$. The concentration of apoAI in the samples was, on average, $0.7 \pm 0.4 \mathrm{mg} / \mathrm{ml}$ (range $0.23-1.20 \mathrm{mg} / \mathrm{ml}$ ). The recovered intimal fluid was stored at $-50^{\circ} \mathrm{C}$ until use.

Other assays. The protein content was determined by the procedure of Lowry et al. (35) with BSA as standard, and $\alpha_{1}$-antitrypsin and apoAI concentrations were determined using commercial kit reagents from Orion Diagnostica (Espoo, Finland).

Statistical analysis. Statistical analysis was carried out using Student's $t$ test for paired samples. Any test yielding a $P$ value of $<0.05$ was taken to indicate a statistically significant difference.

\section{Results}

Effect of granule remnants on lipoprotein-induced cholesterol efflux. Mouse peritoneal macrophages were loaded with radiolabeled cholesterol by incubating them with ${ }^{3} \mathrm{H}$-labeled acetylLDL for $18 \mathrm{~h}$. During incubation, the total cholesterol content of the macrophages increased from $\sim 40$ to $\sim 100 \mu \mathrm{g} / \mathrm{mg}$ cell 


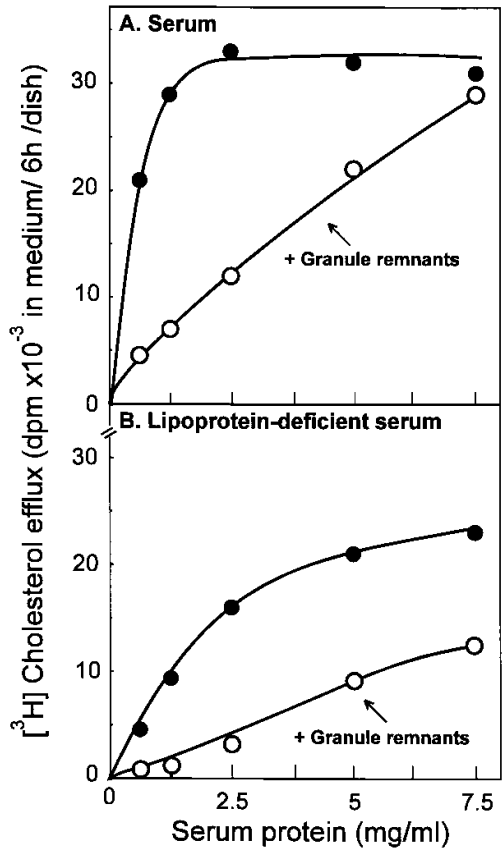

Figure 2. The ability of mast cell granule remnants to inhibit cholesterol efflux from mouse macrophage foam cells promoted by $(A)$ serum or $(B)$ lipoprotein-deficient serum. $\left[{ }^{3} \mathrm{H}\right]$ cholesterol-loaded mouse macrophage foam cells were incubated in 300 $\mu l$ of medium A containing the indicated concentrations of $(A)$ serum or $(B)$ lipoprotein-deficient serum $(d>1.25 \mathrm{~g} / \mathrm{ml})$ in the presence or absence of granule remnants $(6 \mu \mathrm{g} /$ dish). After incubation at $37^{\circ} \mathrm{C}$ for $6 \mathrm{~h}$, the ${ }^{3} \mathrm{H}$ radioactivity of the medium was determined and plotted as a function of protein concentration.

protein, and the cholesteryl ester content from $\sim 5$ to $\sim 60 \mu \mathrm{g} /$ mg cell protein. The $\left[{ }^{3} \mathrm{H}\right]$ cholesterol-loaded macrophage foam cells were then incubated for $6 \mathrm{~h}$ in media containing various concentrations of human serum, and the efflux of $\left[{ }^{3} \mathrm{H}\right]$ cholesterol from the cells into the medium was measured (Fig. $2 \mathrm{~A}$ ). With increasing amounts of serum, the rate of cholesterol efflux from the foam cells increased rapidly to a steady level at a serum protein concentration of $\sim 2.5 \mathrm{mg} / \mathrm{ml}$. Addition of granule remnants to the incubation medium abolished the high-affinity component responsible for the rapid efflux, and, at low serum concentration, greatly reduced the rate of cholesterol efflux from the macrophages. Accordingly, in the presence of granule remnants the efflux process increased almost linearly with serum concentration, and for cholesterol efflux to reach the maximum level obtained without remnants, serum was required at a threefold higher concentration. Similar results were obtained if human blood plasma (containing the thrombin inhibitor PPACK) was used instead of human serum (not shown). If lipoproteins were removed from the serum by prior ultracentrifugation (at $d=1.25 \mathrm{~g} / \mathrm{ml}$ ), the rate of cholesterol efflux was reduced (Fig. $2 \mathrm{~B}$ ). This difference was especially pronounced at low serum protein concentrations, the rate of cholesterol efflux being only $1 / 3$ of that seen in the presence of whole serum. When granule remnants were added to lipoprotein-deficient serum, the rate of cholesterol efflux was reduced still further, being a linear function of protein concentration within the range of protein concentrations studied.

We have previously shown that mast cell granule remnants are able to reduce the ability of human $\mathrm{HDL}_{3}$ to induce cholesterol efflux from macrophage foam cells (10). This was effected by the neutral protease chymase present in the granule remnants, which proteolyzed the $\mathrm{HDL}_{3}$ particles, so rendering them unable to function as cholesterol acceptors. The proteolytic activity of the chymase of granule remnants can be inhibited by treating the remnants with PMSF. When such proteolytically inactivated granule remnants were added to macrophage cultures containing whole serum, there was no

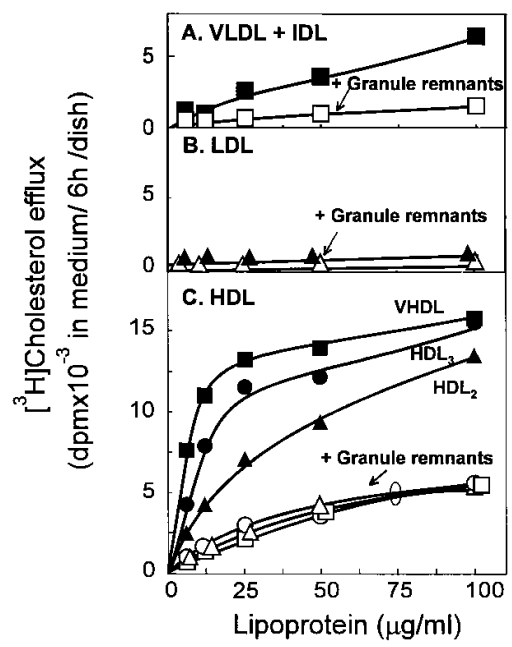

Figure 3. The ability of mast cell granule remnants to inhibit cholesterol efflux from mouse macrophage foam cells promoted by $(A)$

VLDL + IDL, $(B)$ LDL, or $(C)$ HDL. $\left[{ }^{3} \mathrm{H}\right]$ cholesterol-loaded mouse macrophage foam cells were incubated in $300 \mu \mathrm{l}$ of medium A containing the indicated concentrations of VLDL + IDL, LDL, or HDL subfractions in the presence or absence of granule remnants $(6 \mu \mathrm{g} / \mathrm{dish})$. After

incubation at $37^{\circ} \mathrm{C}$ for $6 \mathrm{~h}$, the ${ }^{3} \mathrm{H}$ radioactivity of the medium was determined and plotted as a function of lipoprotein concentration.

significant reduction in cholesterol efflux (not shown). Thus, the efflux-blocking effect of the granule remnants was due to their ability to proteolyze some efflux-promoting components of serum.

To identify the efflux-inducing serum components sensitive to the proteolytic action of granule remnant chymase, we next isolated the following lipoprotein fractions from serum: VLDL + IDL $(d=1.006-1.019 \mathrm{~g} / \mathrm{ml})$, LDL $(d=1.019-1.063 \mathrm{~g} / \mathrm{ml})$, and three different subclasses of HDL: $\mathrm{HDL}_{2}(d=1.063-1.125$ $\mathrm{g} / \mathrm{ml}), \mathrm{HDL}_{3}(d=1.125-1.210 \mathrm{~g} / \mathrm{ml})$, and VHDL $(d=1.21-$ $1.25 \mathrm{~g} / \mathrm{ml}$ ) which was immunopurified on an anti-apoAI affinity column according to Barbaras et al. (26). We then separately tested the ability of these fractions to induce $\left[{ }^{3} \mathrm{H}\right]$ cholesterol efflux from macrophage foam cells in the absence and presence of proteolytically active granule remnants (Fig. 3). As shown in $A$, the VLDL + IDL fraction showed little cholesterol efflux-promoting effect, and this effect was blocked by the granule remnants. The LDL fraction showed only an insignificant cholesterol efflux-promoting effect. In contrast, if the various fractions of serum HDL were added to the incubation medium, the rate of cholesterol efflux rose sharply with increasing concentrations up to $\sim 25 \mu \mathrm{g} / \mathrm{ml}$ of HDL, and then more slowly. VHDL and $\mathrm{HDL}_{3}$ were almost identical in their cholesterol-promoting activities, and $\mathrm{HDL}_{2}$ was somewhat less effective. Incubation of the various HDL subclasses with granule remnants greatly reduced their abilities to induce $\left[{ }^{3} \mathrm{H}\right]$ cholesterol efflux; all three HDL subclasses so treated induced similar low levels of cholesterol efflux.

To elucidate the role of apoAI, the major constituent of all density classes of HDL, in the observed granule remnantmediated inhibition of cholesterol efflux, we next used an apoAI-affinity column to remove apoAI-containing particles (LpAI) from serum. In this LpAI-deficient serum, the rate of cholesterol efflux was considerably lower than in whole serum, whether human or mouse macrophages were used (Fig. 4, $A$ and $B$ ). Addition of granule remnants to whole serum decreased the efflux rates, as observed previously (compare with Fig. 2). In sharp contrast, the granule remnants had no effect on the ability of the LpAI-deficient serum to induce cholesterol efflux. When LpAI particles isolated from serum were incubated with cholesterol-loaded mouse or human macro- 


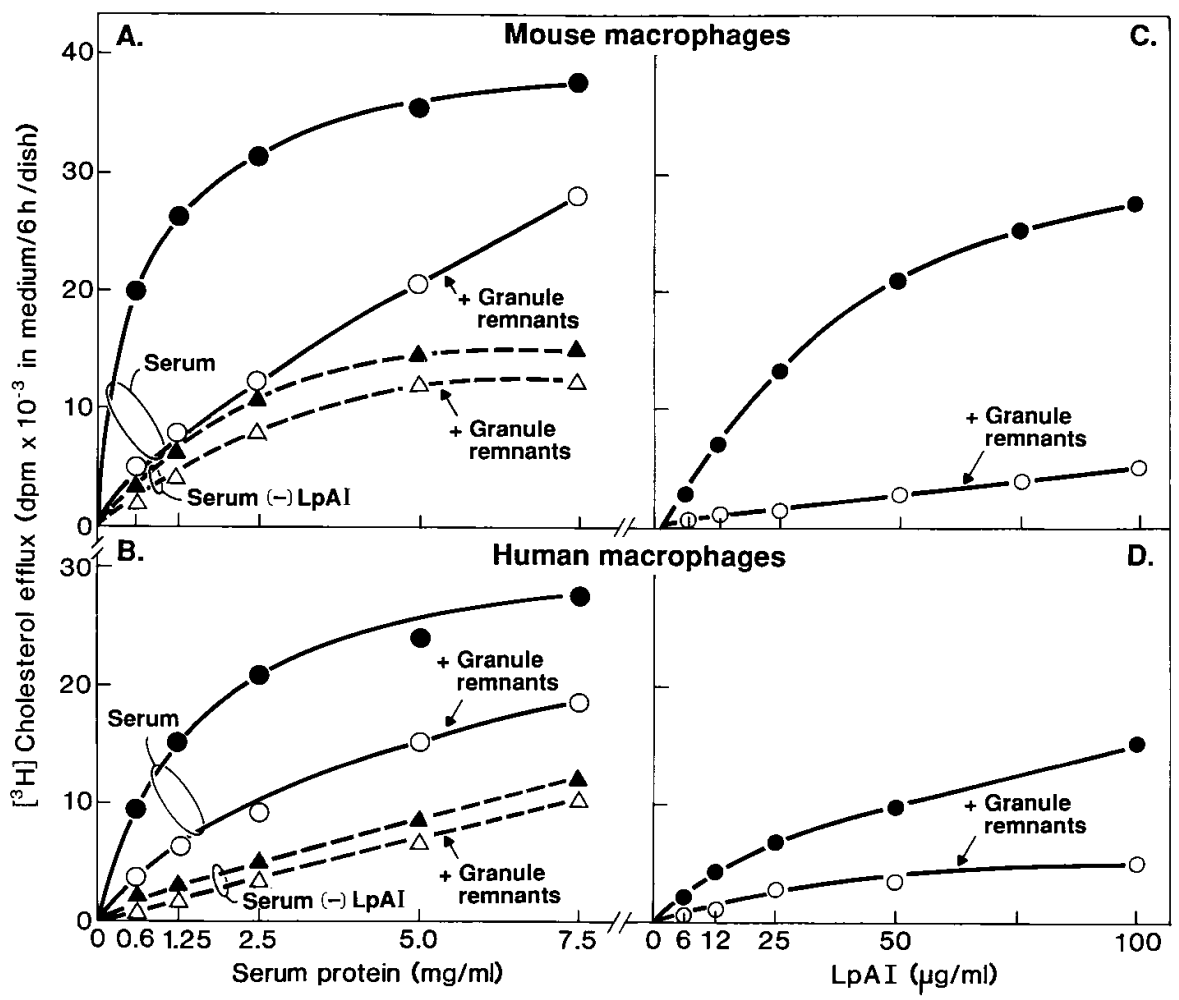

Figure 4. The ability of mast cell granule remnants to inhibit cholesterol efflux from $(A$ and $C$ ) mouse macrophage foam cells or $(B$ and $D)$ human monocytederived macrophage foam cells promoted by $(A$ and $B)$ serum, LpAI-deficient serum, or $(C$ and $D)$ LpAI particles.

$\left[{ }^{3} \mathrm{H}\right]$ cholesterol-loaded macrophage foam cells were incubated in $300 \mu \mathrm{l}$ of medium A containing the indicated concentrations of serum, LpAI-deficient serum [Serum(-)LpAI; dashed line], or LpAI particles in the presence or absence of granule remnants $(6 \mu \mathrm{g} / \mathrm{dish})$. After incubation at $37^{\circ} \mathrm{C}$ for $6 \mathrm{~h}$, the ${ }^{3} \mathrm{H}$ radioactivity of the medium was determined and plotted as a function of lipoprotein concentration. phages in the presence or absence of granule remnants, the results were similar to those obtained with HDL (Fig. 4, $C$ and $D)$. Thus, when the concentration of LpAI was increased, the rate of cholesterol efflux rose and, on addition of granule remnants, apoAI-induced cholesterol efflux from both cell types was strongly inhibited to the same low level.

To investigate the integrity of apoAI and apoAII in various acceptors after granule treatment, we degraded intimal fluid, serum, LpAI and $\mathrm{HDL}_{3}$ with granule remnants at $37^{\circ} \mathrm{C}$ for $18 \mathrm{~h}$ and subjected them to immunoblotting. The granule remnanttreated samples contained, not only intact apoAI, but also fragments with estimated molecular weights ranging from $\sim 10$ to $26 \mathrm{kD}$ (Fig. $5 A$ ). After treatment with granule remnants, a new band became visible in the Western blot of apoAII, with an estimated molecular mass of $\sim 10 \mathrm{kD}$ (Fig. 5 $B)$. Since the granule remnants degraded both apoAI and apoAII, we next studied the effect of the remnants on the functional properties of the two apolipoproteins separately. For this purpose, $\mathrm{HDL}_{3}$ was divided by immunoaffinity chromatography into two particle populations according to the apolipoprotein content: one containing apoAI and apoAII $\left[\mathrm{HDL}_{3}(\mathrm{AI} w \mathrm{AII})\right]$, and the other containing apoAI, but not apoAII $\left[\mathrm{HDL}_{3}(\mathrm{AI}\right.$ w/o AII)] (26). The particles in both populations promoted cholesterol efflux from cholesterol-loaded human monocyte-derived macrophages, and in both cases addition of granule remnants to the system decreased the efflux (Table I).

Determination of the cellular cholesteryl ester content of mouse macrophage foam cells revealed that all the acceptors which induced efflux of $\left[{ }^{3} \mathrm{H}\right]$ cholesterol were also able to induce net efflux of cholesterol from the foam cells (Table II). Moreover, in each case, treatment with proteolytically active granule remnants significantly reduced the acceptor-induced net efflux of cholesterol. Human monocyte-derived macrophages also released cholesterol when incubated with $\mathrm{HDL}_{3}$, and this net efflux was significantly reduced if the $\mathrm{HDL}_{3}$ had been pretreated with mast cell granule remnants.

Susceptibility of granule remnants and isolated chymase to inhibition with proteaze inhibitors. The ability of granule remnants to proteolyze and so inactivate the cholesterol effluxpromoting components of serum revealed that, in the presence of the natural protease inhibitors in serum, the activity of granule remnant chymase was not totally inhibited. In the granule remnants, chymase is embedded in a heparin proteoglycan matrix, where it is tightly bound to heparin glycosaminoglycan chains (13). To investigate the relevance of the spatial relations between chymase and heparin proteoglycans in the rem-

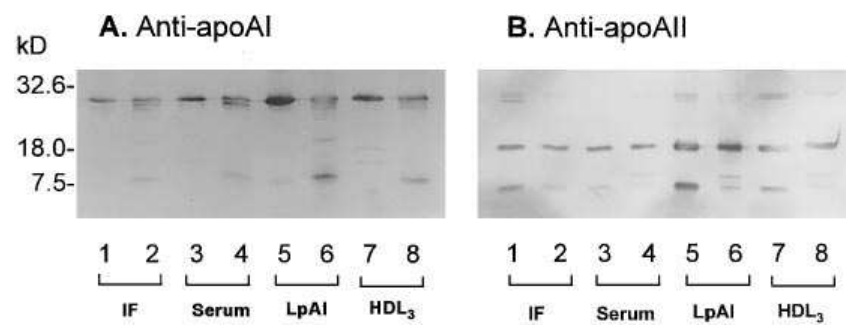

Figure 5. Western blots of $(A)$ apoAI or $(B)$ apoAII of granule remnant-treated intimal fluid, serum, $\mathrm{LpAI}$, and $\mathrm{HDL}_{3}$. Intimal fluid $(2 \%)$, serum $(1 \%)$, LpAI $(1 \mathrm{mg} / \mathrm{ml})$, or $\mathrm{HDL}_{3}(1 \mathrm{mg} / \mathrm{ml})$ were incubated at $37^{\circ} \mathrm{C}$ for $18 \mathrm{~h}$ in $50 \mu \mathrm{l}$ of a mixture comprising $150 \mathrm{mM} \mathrm{NaCl}$, $1 \mathrm{mM}$ EDTA, and $5 \mathrm{mM}$ Tris-HCl, $\mathrm{pH} 7.4$, in the presence or absence of $5 \mu \mathrm{g}$ of granule remnants. After incubation, aliquots of treated and untreated samples were applied to 15\% SDS-PAGE gel in nonreducing conditions, and transferred to a nitrocellulose membrane, and apoAI and apoAII were immunolocalized. In $A$ and $B$ : Lane 1 , intimal fluid; lane 2, granule-treated intimal fluid; lane 3, serum; lane 4, granule-treated serum; lane 5, LpAI; line 6, granule-treated LpAI; line $7, \mathrm{HDL}_{3}$; line 8 , granule-treated $\mathrm{HDL}_{3}$. Molecular weight standards: soybean trypsin inhibitor $(32.6 \mathrm{kD})$, lysozyme $(18 \mathrm{kD})$, and aprotinin $(7.5 \mathrm{kD})$. 
Table I. Ability of Mast Cell Granule Remnants to Inhibit Cholesterol Efflux from Cholesterol-loaded Human Monocyte-derived Macrophages Promoted by $\mathrm{HDL}_{3}$ (AI w/o AII) or HDL $\mathrm{H}_{3}$ (AI w AII)

\begin{tabular}{|c|c|c|c|c|}
\hline \multirow[b]{3}{*}{ Acceptor } & \multicolumn{4}{|c|}{ Efflux of cholesterol } \\
\hline & \multicolumn{2}{|c|}{ Experiment A } & \multicolumn{2}{|c|}{ Experiment B } \\
\hline & $(-)$ Granule remnants & $(+)$ Granule remnants & $(-)$ Granule remnants & $(+)$ Granule remnants \\
\hline & \multicolumn{4}{|c|}{$\left[{ }^{3} \mathrm{H}\right]$ cholesterol in medium, dpm/dish } \\
\hline $\mathrm{HDL}_{3}$ & $4,700(100)$ & $2,600(55)$ & $13,500(100)$ & $4,100(30)$ \\
\hline $\mathrm{HDL}_{3}$ (AI w/o AII) & $2,600(100)$ & $1,800(69)$ & $6,700(100)$ & $3,000(45)$ \\
\hline $\mathrm{HDL}_{3}(\mathrm{AI}$ w AII $)$ & $4,200(100)$ & $2,000(48)$ & $8,500(100)$ & $3,100(36)$ \\
\hline
\end{tabular}

$\left[{ }^{3} \mathrm{H}\right]$ Cholesterol-loaded human monocyte-derived macrophages were incubated with $25 \mu \mathrm{g} / \mathrm{ml}$ of acceptor particles in the presence or absence of granule remnants $(6 \mu \mathrm{g} / \mathrm{dish})$. After incubation at $37^{\circ} \mathrm{C}$ for $6 \mathrm{~h}$, the ${ }^{3} \mathrm{H}$ radioactivity of the medium was determined. Values for two experiments are shown. Each value is the mean of duplicate incubations. The relative values (in percent) are shown in parentheses.

nants for the ability of the chymase to resist natural protease inhibitors, we isolated and purified the chymase ("isolated chymase," see Methods) and measured the proteolytic activity of this isolated chymase and of granule remnant-bound chymase (i.e., granule remnants) in the presence of serum. For comparison, we also used $\alpha$-chymotrypsin, an endopeptidase with similar specificity to chymase. The proteolytic activities of granule remnant-bound chymase, isolated chymase, and $\alpha$-chymotrypsin (each 17 BTEE units) were determined by measuring the production of TCA-soluble material from ${ }^{125} \mathrm{I}$-labeled apolipoproteins of $\mathrm{HDL}_{3}$ in the absence and presence of $10 \%$ serum (Fig. 6). In the absence of serum, the granule remnantbound chymase and isolated chymase degraded $\mathrm{HDL}_{3}$ at roughly equal rates, but less rapidly than $\alpha$-chymotrypsin. When serum was added to the incubation system, the activities of isolated chymase and $\alpha$-chymotrypsin were almost totally blocked. In contrast, the ability of granule remnants to proteolyze ${ }^{125} \mathrm{I}_{-} \mathrm{HDL}_{3}$ was inhibited by only $\sim 50 \%$, so leaving significant residual proteolytic activity in the presence of serum. Similarly, the chymase in the granule remnants was resistant to the protease inhibitors present in rat serum (data not shown).

The ability of granule remnants to degrade $H D L_{3}$ in the presence of intimal fluid. We next collected intimal fluid from four human aortas (of autopsied subjects; see Methods), and compared the abilities of granule remnant-bound chymase and isolated chymase to proteolyze $\mathrm{HDL}_{3}$ in the presence of in-

Table II. Effect of Granule Remnants on Net Efflux of Cholesterol from Macrophage Foam Cells to Various Cholesterol Acceptors

\begin{tabular}{cccc} 
& & Net efflux of cholesterol \\
\cline { 3 - 4 } & Acceptor & $(-)$ Granule remnants & $(+)$ Granule remnants \\
\hline
\end{tabular}

$\mu \mathrm{g}$ cholesteryl esters/mg cell protein

\footnotetext{
Mouse macrophages $(n=4)$

Serum $(1.5 \mathrm{mg} / \mathrm{ml})$

LPDS $(1.5 \mathrm{mg} / \mathrm{ml})$

Serum w/o LpAI $(1.5 \mathrm{mg} / \mathrm{ml})$

$\mathrm{HDL}_{2}(25 \mu \mathrm{g} / \mathrm{ml})$

$\mathrm{HDL}_{3}(25 \mu \mathrm{g} / \mathrm{ml})$

VHDL $(25 \mu \mathrm{g} / \mathrm{ml})$

LpAI $(25 \mu \mathrm{g} / \mathrm{ml})$
}

$$
\begin{aligned}
& -13 \pm 9 \\
& -16 \pm 12 \\
& -3 \pm 5 \\
& -11 \pm 9 \\
& -16 \pm 11 \\
& -14 \pm 9 \\
& -10 \pm 8
\end{aligned}
$$$$
-35 \pm 18
$$

0.014

0.050

0.528

0.098

0.002

0.010

0.033

0.016

Mouse macrophages (containing, on average, $4.3 \mu \mathrm{g}$ cholesteryl esters $/ \mathrm{mg}$ cell protein) were incubated with $20 \mu \mathrm{g} / \mathrm{ml}$ of acetyl-LDL for $18 \mathrm{~h}$. The cholesterol-loaded mouse macrophages (foam cells containing, on average, $62 \mu \mathrm{g}$ cholesteryl esters $/ \mathrm{mg}$ cell protein) were then washed, and fresh medium containing the indicated concentrations of the indicated acceptors was added, in the absence (left column) or presence (middle column) of granule remnants $(6 \mu \mathrm{g} / \mathrm{dish})$. Human monocyte-derived macrophages (containing, on average, $2.5 \mu \mathrm{g}$ cholesteryl esters $/ \mathrm{mg}$ cell protein) were incubated with $25 \mu \mathrm{g} / \mathrm{ml}$ of acetyle-LDL for $48 \mathrm{~h}$. The cholesterol-loaded human macrophages (foam cells containing, on average, $93 \mu \mathrm{g}$ cholesteryl esters $/ \mathrm{mg}$ cell protein) were then washed, fresh medium was added containing the indicated concentration of either control $\mathrm{HDL}_{3}\left(\right.$ left column) or $\mathrm{HDL}_{3}$ which had been pretreated with $20 \mu \mathrm{g} / \mathrm{ml}$ granule remnants for $18 \mathrm{~h}$ (middle column). After incubation at $37^{\circ} \mathrm{C}$ for $6 \mathrm{~h}$ (mouse macrophages) or for $12 \mathrm{~h}$ (human monocyte-derived macrophages), the cellular cholesteryl ester contents were determined (see Methods). The net cholesterol efflux from the macrophage foam cells is the difference between the cellular cholesteryl ester contents before and after incubation with the indicated acceptors. Values are means \pm SD. Each mean is the average of triplicate incubations from a single experiment. The total number of experiments with mouse macrophages was 4, and with human macrophages 8 . Negative values $(-)$ represent decreases, and positive values (+) (one case) increases in cellular cholesteryl ester content. $P$ values (right column) were determined by Student's $t$ test for paired samples. 


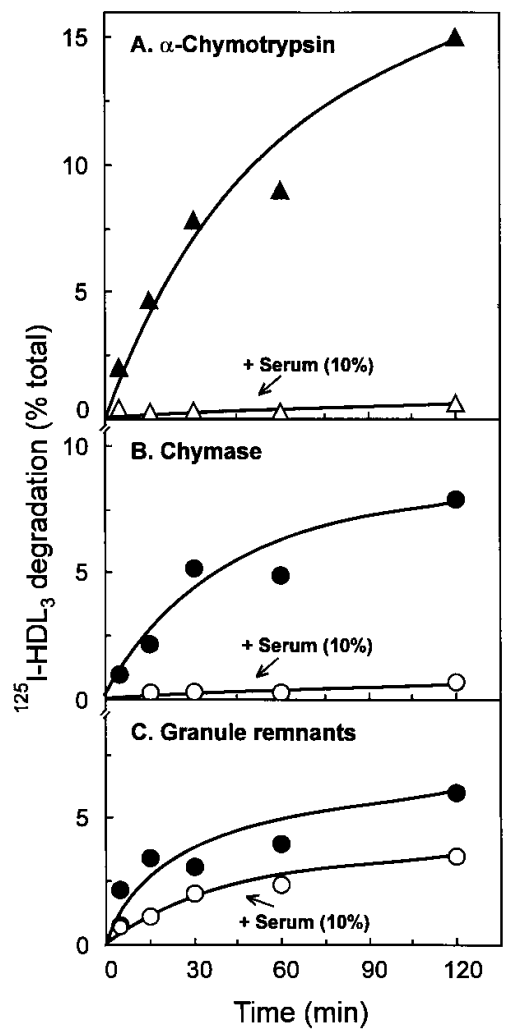

Figure 6. Degradation of $\mathrm{HDL}_{3}$ by $(A) \alpha$-chymotrypsin, $(B)$ isolated chymase, or $(C)$ mast cell granule remnants in the presence of serum. ${ }^{125} \mathrm{I}-\mathrm{HDL}_{3}(0.6 \mathrm{mg} /$ $\mathrm{ml}, 0.5 \mathrm{cpm} / \mathrm{ng}$ ) was incubated at $37^{\circ} \mathrm{C}$ for $2 \mathrm{~h}$ in a mixture consisting of $100 \mu \mathrm{l}$ of $150 \mathrm{mM}$ $\mathrm{NaCl}, 1$ mM EDTA, and $5 \mathrm{mM}$ Tris-HCl, $\mathrm{pH}$ 7.4 , with $\alpha$-chymotrypsin (17 BTEE units), with isolated chymase (17 BTEE units), or with granule remnants (17 BTEE units) in the presence or absence of $10 \%$ serum. After incubation, the amount of TCA-soluble ${ }^{125}$ I radioactivity was determined, calculated in percent of total ${ }^{125}$ I radioactivity in $\mathrm{HDL}_{3}$, and plotted as a function of time.

creasing concentrations of the intimal fluid. In each of the four cases studied, intimal fluid strongly inhibited the proteolytic activity of the isolated chymase, inhibition being total when the proportion of intimal fluid reached 16\% (Fig. 7). At the same concentration of intimal fluid, inhibition of granule remnant-bound chymase was much weaker and varied considerably from case to case. Even at the highest concentration of intimal fluid used (64 vol\%), inhibition was not total, the remaining activity ranging from 10 to $50 \%$ of the control values observed in the absence of intimal fluid.

Finally, to study if the observed residual proteolytic activity of granule chymase in the intimal fluid was sufficient to inhibit the cholesterol efflux-promoting activity of intimal fluid, we incubated cholesterol-loaded human monocyte-derived macrophages in intimal fluid from two additional human aortas (cases 5 and 6), and measured the rate of cholesterol efflux (Fig. 8, $A$ and $B$ ). When increasing amounts (up to $2.5 \mathrm{vol} \%$ ) of intimal fluid were present in the incubation medium, the efflux of cholesterol from the loaded human monocyte-derived macrophages at first rose sharply and then more slowly. If the intimal fluid was pretreated with granule remnants, the highaffinity component of the efflux was eliminated.

\section{Discussion}

The present study demonstrates that exocytosed mast cell granules can proteolytically modify serum and aortic intimal fluid - a physiological ultrafiltrate of serum - and so prevent these two fluids from effectively promoting cholesterol efflux from macrophage foam cells. Our study of this proteolytic system led us to identify two components of the cholesterol efflux mechanism, one protease-sensitive and the other protease-insensitive. The protease-sensitive component rose sharply to a saturation level at a low serum total protein concentration; this

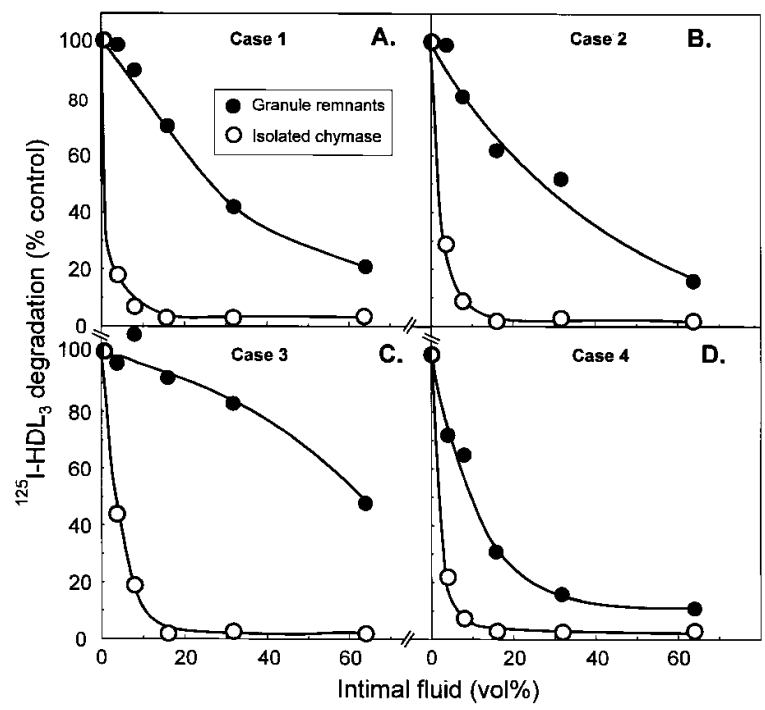

Figure 7. Degradation of $\mathrm{HDL}_{3}$ by mast cell granule remnants or isolated chymase in the presence of extracellular fluid obtained from human aortic intima. ${ }^{125} \mathrm{I}-\mathrm{HDL}_{3}(0.6 \mathrm{mg} / \mathrm{ml}, 0.5 \mathrm{cpm} / \mathrm{ng})$ was incubated at $37^{\circ} \mathrm{C}$ for $2 \mathrm{~h}$ in $20 \mu \mathrm{l}$ of a mixture comprising $150 \mathrm{mM} \mathrm{NaCl}, 1 \mathrm{mM}$ EDTA, and $5 \mathrm{mM}$ Tris-HCL, $\mathrm{pH} 7.4$, with granule remnants $(10 \mu \mathrm{g}$; 17 BTEE units) or isolated chymase (17 BTEE units) in the presence of $4,8,16,32$ and $64 \%(\mathrm{vol} / \mathrm{vol})$ of intimal fluid obtained from four aortic samples. After incubation, the amounts of TCA-soluble ${ }^{125} \mathrm{I}$ radioactivity were determined, calculated as percents of the ${ }^{125} \mathrm{I}_{-} \mathrm{HDL}_{3}$ degradation in the absence of intimal fluid (control), and plotted as a function of inhibitor concentration. In the different cases, the control values $(100 \%)$ for granule remnants and isolated chymase, respectively, were 8 and $11 \%$ (case 1), 9 and 12\% (case 2), 13 and 22\% (case 3 ), and 14 and $23 \%$ (case 4 ) of the total ${ }^{125}$ I radioactivity in $\mathrm{HDL}_{3}$.

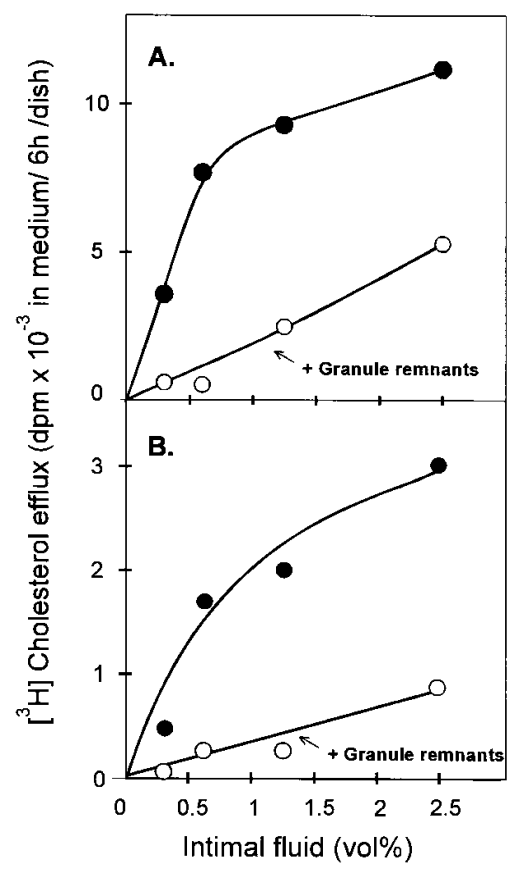

Figure 8. The ability of mast cell granule remnants to inhibit cholesterol efflux from cholesterol-loaded human monocyte-derived macrophages promoted by aortic intimal fluid. Samples of aortic intimal fluid $(2.5 \mathrm{vol} \%)$ obtained from two aortic specimens $(A$ and $B)$ were incubated at $37^{\circ} \mathrm{C}$ for $18 \mathrm{~h}$ in the absence or presence of $50 \mu \mathrm{g} / \mathrm{ml}$ of granule remnants in medium A. After incubation, the granules were removed by centrifugation, and various volumes of the treated intimal fluid were added to cholesterolloaded macrophage monolayers. Medium A was then added to give the indicated concentrations (vol\%) of intimal fluid in a final volume of $300 \mu \mathrm{l}$. After incubation at $37^{\circ} \mathrm{C}$ for $6 \mathrm{~h}$, the ${ }^{3} \mathrm{H}$ radioactivity of the medium in each dish was determined and plottted as a function of intimal fluid concentration. 
component was designated the "high-affinity cholesterol efflux-promoting component" of serum. Removal of apoAI-containing particles from serum was accompanied by simultaneous loss of the capacity for high-affinity efflux and of the protease sensitivity of the serum, showing that the proteasesensitive serum component responsible for the high affinity efflux contained apolipoprotein AI. The result was similar if the total HDL fraction ( $d=1.063-1.215 \mathrm{~g} / \mathrm{ml}$; not shown), one of its subfractions $\mathrm{HDL}_{2}, \mathrm{HDL}_{3}, \mathrm{VHDL}$, or a suspension of apoAI-containing particles was used instead of serum. The lipoprotein-deficient serum $(d>1.25)$, which still contained free apoAI, possessed a smaller amount of the high affinity efflux-promoting component, which was protease-sensitive (compare Fig. 2, $A$ and $B$ ). Thus, the exocytosed mast cell granules proteolytically incapacitated the components of serum that are most closely associated with cholesterol efflux from cells (36).

A fraction of the lipoproteins in HDL particles responsible for the high-affinity cholesterol-efflux promoting activity of serum contain, not only apoAI, but also apoAII (37). By isolating lipoprotein particles from the apoE-free $\mathrm{HDL}_{3}$ fraction containing apoAI but not apoAII, and particles that contain both apoAI and apoAII, and treating them with mast cell granules, we showed that both of these physiological particle classes promote cholesterol efflux from macrophage foam cells, and that this activity is sensitive to protease treatment. However, since some of the LpAI and LpAI/AII also contain apoAIV, we cannot draw conclusions about the relative importance of the various apoAs of these particles in the protease-sensitive high-affinity efflux of cholesterol. Interestingly, Oram et al. (38), who treated the $\mathrm{HDL}_{3}$ density fraction of serum with either trypsin or pronase, observed that, after extensive proteolytic treatment, the protease-modified $\mathrm{HDL}_{3}$ particles contained no detectable intact apoAII and only small amounts of intact apoAI. The ability of such protease-modified $\mathrm{HDL}_{3}$ to promote cholesterol efflux from cholesterolloaded fibroblasts was greatly reduced.

The other major observation in the present study was that the proteolytic activity (i.e., chymase activity) of mast cell granule remnants resists the protease inhibitors present in serum. The type of experimentation used did not allow us to draw conclusions about the mechanism responsible for this resistance. However, once the chymase was released from the heparin proteoglycan matrix of the granule remnants, its resistance was lost, an observation which shows the importance of heparin binding for the maintenance of chymase activity in a serum-containing medium. It is this resistance to proteinase inhibitors which enables the granule remnants to remain partially active in fluids containing both the target molecules and the physiological inhibitors of chymase, i.e., in serum and intimal fluid. The conclusion that chymase is protected against protease inhibitors when bound to the heparin proteoglycans of the granule remnants is further supported by the findings that addition of isolated chymase or commercial $\alpha$-chymotrypsin to serum failed to cause any degradation of $\mathrm{HDL}_{3}$ or to reduce the ability of serum to induce cholesterol efflux from macrophage foam cells. Since the other commercially available serine proteases commonly used, such as trypsin or pronase, are known to be sensitive to inhibition by proteinase inhibitors, it is likely that, if added to serum or to intimal fluid, they would fail to degrade and inactivate the apoAs. The mechanism involved in the chymase resistance to natural inhibitors is now being subjected to further studies in our laboratory.
Chymase is the first natural protease present in the arterial intima (15-17) that has been found to inhibit cholesterol efflux from macrophage foam cells in vitro. We also found that human skin chymase (39) effectively degrades the apolipoproteins of $\mathrm{HDL}_{3}$ (data not shown). Several other proteolytic enzymes are secreted by cells present in the arterial intima, e.g., macrophages, smooth muscle cells, and T lymphocytes, and these proteases could also potentially act on apoAI (and apoAII and apoAIV) (40-43). Furthermore, plasmin, thrombin, and kallikrein, three plasma-derived enzymes which have also been found in the arterial intima $(44,45)$, have been shown to cleave apoAI (46). It remains to be shown which of these proteolytic enzymes are present in active form in the intimal fluid. Our findings emphasize the importance of studying enzymes in their physiological form (e.g., chymase bound to granule heparin), instead of in isolated and purified forms. Indeed, even plasmin is protected from its natural inhibitors only when bound to specific receptors on cellular (or bacterial) surfaces (47).

The resistance of the proteolytic activity of granule remnants to protease inhibitors was only partial and highly variable. The reason for this variation has not yet been elucidated. In one autopsy case we compared the concentrations of $\alpha_{1}$-antitrypsin in the intimal fluid and serum, and found that the concentration in intimal fluid was $40 \%$ of that in serum, a result according with those of Smith et al. (19). Moreover, the two other proteinase inhibitors to which chymase is sensitive, $\alpha_{2}$ macroglobulin and $\alpha_{1}$-antichymotrypsin, are likely to filter into extracellular fluids such as the intimal fluid. Thus, the actual degree of chymase inhibition in the intimal fluid probably depends on the concentrations of the various protease inhibitors in this body fluid. Because of the small volumes of intimal fluid available, we did not make a systematic study of this point. In a previous study, we found that degradation of the apoliproteins of $\mathrm{HDL}_{3}$ by $<5 \%$ is sufficient to impede the cholesterol efflux-promoting ability of these particles (10). We did not determine which lipoprotein particles in the intimal fluid were responsible for its cholesterol efflux-inducing capacity. However, in immunoblots we detected signs indicating degradation of both apoAI and apoAII. Recent observations with lymphatic fluid and with sophisticated in vitro systems have suggested that the process of cholesterol efflux from cells into the extracellular fluid in vivo does involve a specific subgroup of HDL particles, the preßHDL (48-50). These particles contain apoAI as their sole apolipoprotein, and the conformation of apoAI in the preßHDL appears to render it exquisitely sensitive to proteolytic cleavage (46). Thus, the most likely candidates for the protease-sensitive high-affinity efflux in the intimal fluid are the pre $\beta$ particles.

In summary, the present findings show that in the aortic intimal fluid, a fraction of the cholesterol efflux-promoting activity is sensitive to proteolytic inhibition. It remains to be investigated whether the other suggested antiatherogenic properties of apoAI-containing lipoproteins, such as antioxidant, antithrombotic, or anti-inflammatory properties (51), are affected by proteolytic degradation of apoAI. Since mast cell granules inhibit the high-affinity component of the efflux process at low levels of acceptor particles, the inhibitory mechanism described in this paper is likely to have a significant effect when the level of HDL particles in blood plasma, and consequently also in intimal fluid, is low. As yet, however, we cannot measure the extent to which intimal mast cells inhibit the local ef- 
flux of cholesterol from macrophage foam cells in the arterial wall. Recent observations that the numbers of degranulated mast cells in the foam cell-containing areas of human aorta and coronary arteries (15-17) are increased would suggest that, in the atherosclerosis-prone areas of the arterial wall, mast cells can alter the delicate balance between cholesterol influx and efflux, and so contribute to the formation and maintenance of foam cells in these vulnerable intimal areas.

\section{References}

1. Miller, G.J., and N.E. Miller. 1975. Plasma high density lipoprotein concentration and development of ischaemic heart disease. Lancet. i:16.

2. Badimon, J.J., L. Badimon, and V. Fuster. 1990. Regression of atherosclerotic lesion by high density lipoprotein plasma fraction in the cholesterolfed rabbit. J. Clin. Invest. 85:1234-1241.

3. Kovanen, P.T. 1990. Atheroma formation: defective control in the intimal round-trip of cholesterol. Eur. Heart J. 11(suppl E):238-246.

4. Fielding, C.J., and P.E. Fielding. 1995. Molecular physiology of reverse cholesterol transport. J. Lipid Res. 36:211-228.

5. Johnson, W.J., F.H. Mahlberg, G.H. Rothblat, and M.C. Phillips. 1991. Cholesterol transport between cells and high-density lipoproteins. Biochim. Biophys. Acta. 1085:273-298.

6. Brown, M.S., and J.L. Goldstein. 1983. Lipoprotein metabolism in the macrophage: implications for cholesterol deposition in atherosclerosis. Annu. Rev. Biochem. 52:223-261.

7. Fogelman, A.M., B.J. van Lenten, C. Warden, M.E. Haberland, and P.A. Edwards. 1988. Macrophage lipoprotein receptors. J. Cell. Sci. 9(suppl): 135-149.

8. Hoff, H.F., J. O'Neil, J.M. Pepin, and T.B. Cole. 1990. Macrophage uptake of cholesterol-containing particles derived from LDL and isolated from atherosclerotic lesions. Eur. Heart J. 11(suppl E):105-115.

9. Lindstedt, K.A., J.O. Kokkonen, and P.T. Kovanen. 1992. Soluble heparin proteoglycans released from stimulated mast cells induce uptake of low density lipoproteins by macrophages via scavenger receptor-mediated phagocytosis. J. Lipid. Res. 33:65-75.

10. Lee, M., L. Lindstedt, and P.T. Kovanen. 1992. Mast cell-mediated inhibition of reverse cholesterol transport. Arterioscler. Thromb. 12:1329-1335.

11. Schwartz, L.B., and K.F. Austen. 1984. Structure and function of the chemical mediators of mast cells. Prog. Allergy. 34:271-321.

12. Röhlich, P., P. Anderson, and B. Uvnäs. 1971. Electron microscope observations on compound 48/80-induced degranulation in rat mast cells. Evidence for sequential exocytosis of storage granules. J. Cell Biol. 51:465-483.

13. Kovanen, P.T. 1993. The mast cell—a potential link between inflammation and cellular cholesterol deposition in atherogenesis. Eur. Heart J. 14(suppl K):105-117.

14. Kovanen, P.T. 1991. Mast cell granule-mediated uptake of low density lipoproteins by macrophages: a novel carrier mechanism leading to the formation of foam cells. Ann. Med. 23:551-559.

15. Kaartinen, M., A. Penttilä, and P.T. Kovanen. 1994. Mast cells of two types differing in neutral protease composition in the human aortic intima. Demonstration of tryptase- and tryptase/chymase-containing mast cells in normal intimas, fatty streaks, and the shoulder region of atheromas. Arterioscler. Thromb. 14:966-972.

16. Kaartinen, M., A. Penttilä, and P.T. Kovanen. 1994. Accumulation of activated mast cells in the shoulder region of human coronary atheroma, the predilection site of atheromatous rupture. Circulation. 90:1669-1678.

17. Kaartinen, M., A. Penttilä, and P.T. Kovanen. 1995. Extracellular mast cell granules carry apolipoprotein B-100-containing lipoproteins into phagocytes in human arterial intima. Functional coupling of exocytosis and phagocytosis in neighboring cells. Arterioscler. Thromb. Vasc. Biol. 15:2047-2054.

18. Schechter, N.M., J.L. Sprows, O.L. Schoenberger, G.S. Lazarus, B.S. Cooperman, and H. Rubin. 1989. Reaction of human skin chymotrypsin-like proteinase chymase with plasma proteinase inhibitors. J. Biol. Chem. 264: 21308-21315.

19. Smith, E.B. 1990. Transport, interactions and retention of plasma proteins in the intima: the barrier function of the internal elastic lamina. Eur. Heart J. 11(suppl E):72-81.

20. Kido, H., N. Fukusen, and N. Katunuma. 1985. Chymotrypsin- and trypsin-type serine proteases in rat mast cells: properties and functions. Arch. Biochem. Biophys. 239:436-443.

21. Woodbury, R.G., M.T. Everitt, and H. Neurath. 1981. Mast cell proteases. Methods Enzymol. 80:588-609.

22. Kokkonen, J.O., M. Vartiainen, and P.T. Kovanen. 1986. Low density lipoprotein degradation by secretory granules of rat mast cells. J. Biol. Chem. 261:16067-16072.

23. Ho, Y.K., M.S. Brown, and J.L. Goldstein. 1980. Hydrolysis and excretion of cytoplasmic cholesterol esters by macrophages: stimulation by high density lipoprotein and other agents. J. Lipid Res. 21:391-398.
24. Havel, R.J., H.A. Eder, and J.H. Bragdon. 1955. The distribution and chemical composition of ultracentrifugally separated lipoproteins in human serum. J. Clin. Invest. 34:1345-1353.

25. Radding, C.M., and D. Steinberg. 1960. Studies on the synthesis and secretion of serum lipoproteins by rat liver slices. J. Clin. Invest. 39:1560-1569.

26. Barbaras, R., P. Puchois, J.C. Fruchart, and G. Ailhaud. 1987. Cholesterol efflux from cultured adipose cells is mediated by LpAI particles but not LpAI: All particles. Biochem. Biophys. Res. Commun. 142:63-69.

27. Towbin, H., T. Staehelin, and J. Gordon. 1979. Electrophoretic transfer of proteins from polyacrylamide gels to nitrocellulose sheets: procedure and some applications. Proc. Natl. Acad. Sci. USA. 76:4350-4354.

28. Basu, S.K., J.L. Goldstein, R.G.W. Anderson, and M.S. Brown. 1976. Degradation of cationized low density lipoprotein and regulation of cholesterol metabolism in homozygous familial hypercholesterolemia fibroblasts. Proc. Natl. Acad. Sci. USA. 73:3178-3182.

29. Brown, M.S., S.E. Dana, and J.L. Goldstein. 1975. Receptor-dependent hydrolysis of cholesterol esters contained in plasma low density lipoprotein. Proc. Natl. Acad. Sci. USA. 72:2925-2929.

30. McFarlane, A.S. 1958. Efficient trace-labeling of proteins with iodine. Nature (Lond.). 182:53.

31. Bilheimer, D.W., S. Eisenberg, and R.I. Levy. 1972. The metabolism of very low density lipoproteins. I. Preliminary in vitro and in vivo observations. Biochim. Biophys. Acta. 260:212-221.

32. Piha, M., L. Lindstedt, and P.T. Kovanen. 1995. Fusion of low-density lipoprotein in the fluid phase: a novel mechanism generating atherogenic lipoprotein particles. Biochemistry. 34:10120-10129.

33. Laemmli, U.K. 1970. Cleavage of structural proteins during the assembly of the head of bacteriophage T4. Nature (Lond.). 227:680-685.

34. Smith, E.B., and E.M. Staples. 1982. Plasma protein concentrations in interstitial fluid from human aortas. Proc. R. Soc. Lond. B 217:59-75.

35. Lowry, O.H., N.J. Rosebrough, A.L. Farr, and R.J. Randall. 1951. Protein measurement with Folin phenol reagent. J. Biol. Chem. 193:265-275.

36. de la Llera Moya, M., V. Atger, J.L. Paul, P.N. Fournier, N. Moatti, P. Giral, K.E. Friday, and G. Rothblat. 1994. A cell culture system for screening human serum for ability to promote cellular cholesterol efflux: relations between serum components and efflux, esterification, and transfer. Arterioscler. Thromb. 14:1056-1065.

37. Johnson, W.J., E.P.C. Kilsdonk, A. van Tol, M.C. Phillips, and G.H. Rothblat. 1991. Cholesterol efflux from cells to immunopurified subfractions of human high density lipoprotein: LP-AI and LP-AI/AII. J. Lipid. Res. 32:19932000 .

38. Oram, J.F., A.J. Mendez, J.P. Slotte, and T.F. Johnson. 1991. High density lipoprotein apolipoproteins mediate removal of sterol from intracellular pools but not from plasma membranes of cholesterol-loaded fibroblasts. Arterioscler. Thromb. 11:403-414.

39. Saarinen, J., N. Kalkkinen, H.G. Welgus, and P.T. Kovanen. 1994. Activation of human interstitial procollagenase through direct cleavage of the $\mathrm{Leu}^{83}-\mathrm{Thr}^{84}$ bond by mast cell chymase. J. Biol. Chem. 269:18134-18140.

40. Seydewitz, V., and J. Staubesand. 1988. Immunocytochemical demonstration of lysosomal matrix vesicles in the arterial wall of the rat. Histochemistry. 88:463-467.

41. Mitchinson, M.J., and R.Y. Ball. 1987. Macrophages and atherogenesis. Lancet. ii:146-148.

42. Jonasson, L., J. Holm, O. Skalli, G. Bondjers, and G.K. Hansson. 1986. Regional accumulation of T cells, macrophages, and smooth muscle cells in the human atherosclerotic plaque. Atherosclerosis. 6:131-138.

43. Kramer, M.D., and M.M. Simon. 1987. Are proteinases functional molecules of T lymphocytes. Immunol. Today. 8:140-142.

44. Tanaka, K., and K. Sueishi. 1993. The coagulation and fibrinolysis systems and atherosclerosis. Lab. Invest. 69:5-18.

45. Nolly, H., O.A. Carretero, and A.G. Scicli. 1993. Kallikrein release by vascular tissue. Am. J. Physiol. 265:H1209-H1214.

46. Kunitake, S.T., G.C. Chen, S. Kung, J.W. Schilling, D.A. Hardman, and J.P. Kane. 1990. Pre-beta high density lipoprotein. Unique disposition of apolipoprotein A-I increases susceptibility to proteolysis. Arterioscler. Thromb. 10: 25-30.

47. Lottenberg, R., D. Minning-Wenz, and D.P. Boyle. 1994. Capturing host plasmin(ogen): a common mechanism for invasive pathogens? Trends Microbiol. 2:20-24.

48. Castro, G.R., and C. Fielding. 1988. Early incorporation of cell-derived cholesterol into pre-beta-migrating high density lipoprotein. Biochemistry. 27: 25-29.

49. Asztalos, B.F., C.H. Sloop, L. Wong, and P.S. Roheim. 1993. Comparison of apo A-I-containing subpopulations of dog plasma and prenodal peripheral lymph: evidence for alteration in subpopulations in the interstitial space. Biochim. Biophys. Acta. 1169:301-304.

50. Kawano, M., T. Miida, J. Fielding, and P.E. Fielding. 1993. Quantitation of prebeta-HDL-dependent and nonspecific components of the total efflux of cellular cholesterol and phospholipid. Biochemistry. 32:5025-5028.

51. Forte, T., and M. McCall. 1994. The role of apolipoprotein A-I-containing lipoproteins in atherosclerosis. Curr. Opin. Lipidol. 5:354-364. 